\title{
Teknik modifikasi ekstraoral radiografi Newman dan Friedman sebagai alternatif radiografi intraoral periapikal pada masa pandemi COVID-19
}

\author{
Indri Kusuma Dewi", Suhardjo Sitam² iD
}

\begin{abstract}
Objectives: This review is aimed to propose a method that could be an alternative in taking intraoral radiographs during the COVID-19 pandemic.

Literature Review: The COVID-19 pandemic is the most concerning health problem in the world today. The transmission of COVID-19 is through direct or close contact with infected secretions or aerosol droplets. Individuals with COVID-19 may be asymptomatic or presymptomatic $(20 \%-86 \%$ of all infections). Thus, patients with undiagnosed COVID19 can come to dental clinics and Oral and Maxillofacial Radiology centers anytime. The Oral

and Maxillofacial Radiology centers from dental clinics can be a source of transmission of COVID-19 to operator and dental patients. In extraoral radiography modification technique of Newman and Friedman, the sensor is placed on the cheek outside of the oral mucosa, so that the sensor does not contact the mucosal fluid from the patient.

Conclusion: Newman and Friedman's extraoral radiography modification techniques can be use as an alternatives to periapical intraoral radiographs to minimize the transmission of COVID-19.

Keywords: COVID-19, extraoral modification radiography, Newman and Friedman

Cite this article: Dewi IK, Sitam S. Teknik modifikasi ekstraoral radiografi Newman dan Friedman sebagai alternatif radiografi intraoral periapikal pada masa pandemi COVID-19. Jurnal Radiologi Dentomaksilofasial Indonesia 2020;4(2) 43-6. https://doi.org/10.32793/jrdi.v4i2.526
\end{abstract}

${ }^{1}$ PPDGS Radiologi Kedokteran Gigi, Fakultas Kedokteran Gigi, Universitas Padjadjaran, Bandung, Indonesia 40132

2Departemen Radiologi Kedokteran Gigi, Fakultas Kedokteran Gigi, Universitas Padjadjaran, Bandung, Indonesia, 40132

*Correspondence to: Indri Kusuma Dewi

凶indri19003@mail.unpad.ac.id

Received on: June 2020 Revised on: July 2020 Accepted on: August 2020

\section{PENDAHULUAN}

Sejak penemuan awal novel coronavirus SARS CoV-2 pada Desember 2019 di kota Wuhan, provinsi Hubei, Cina, yang menyebabkan penyakit coronavirus baru atau COVID-19, telah menyebar di seluruh dunia. Kasus yang dikonfirmasi telah melampaui 140.000 dan masih meningkat. Dalam 8 12 minggu, telah menyebar secara global sehingga World Health Organization (WHO) menyatakannya sebagai pandemi global pada 11 Maret 2020. Pada 14 Maret 2020, pandemi ini telah melibatkan lebih dari 150 negara, dengan penyebaran yang dominan terdapat di Italia, Korea Selatan, Iran, Hong Kong, Makau, Vietnam dan termasuk Indonesia. ${ }^{1}$ Per 27 Mei, Indonesia telah mencatat 23.851 kasus, tertinggi kedua di Asia Tenggara, di belakang Singapura. Dalam hal jumlah kematian, Indonesia menempati urutan kelima di Asia dengan 1.473 kematian. $^{2} \quad$ Namun, tinjauan ulang data menunjukkan bahwa jumlah kematian mungkin jauh lebih tinggi daripada yang dilaporkan dikarenakan mereka yang meninggal dengan gejala COVID-19 akut tetapi belum dikonfirmasi atau terdiagnosis tidak dihitung dalam angka kematian resmi. Sejumlah besar kematian pada orang tua dan pada pasien dengan komorbiditas multiple telah dilaporkan.

Instalasi Radiologi Kedokteran Gigi dari suatu klinik atau rumah sakit gigi dapat menjadi sumber penularan COVID19 kepada operator dan pasien gigi. Karena penularan COVID-19 orang-ke-orang dapat melalui tetesan pernapasan dan aerosol melalui batuk yang diinduksi dari sensor intraoral harus dicegah dengan mengikuti pedoman pengendalian infeksi COVID-19, termasuk penggunaan peralatan perlindungan pribadi yang sesuai untuk praktisi gigi dan operator. ${ }^{3}$ Pada Teknik intraoral periapikal sensor intraoral dimasukan ke dalam rongga mulut sehingga dapat menjadi sumber penularan dari COVID-19. Dengan teknik modifikasi ekstraoral radiografi Newman dan Friedman dapat menjadi alternatif radiografi intraoral periapikal. Pada teknik ini sensor intraoral diletakan di luar dari mukosa mulut sehingga dapat mengurangi penularan COVID-19. Artikel ini menjelaskan tentang Teknik modifikasi ekstraoral radiografi Newman dan friedman sebagai alternatif radiografi intraoral periapikal pada masa pandemi COVID-19.

\section{STUDI PUSTAKA}

Radiografi periapikal banyak dipakai dalam bidang kedokteran gigi untuk melihat informasi detail tentang gigi dan jaringan tulang alveolar. Teknik periapikal intraoral terdiri dari teknik 
periapikal bisektris dan teknik periapikal pararel. Teknik ini digunakan untuk mendeteksi infeksi apikal/inflamasi, penilaian status periodontal, gig yang mengalami trauma pada tulang alveolar, penilaian kehadiran dan posisi pada gigi yang tidak erupsi, bidang endodontik, penilaian sebelum dan setelah operasi bedah apikal, evaluasi tentang kista dan lesi lain pada apikal dan tulang alveolar, serta evaluasi post-implant. ${ }^{4,5,6}$ Pada masa pandemi COVID-19, radiograf intraoral sangat tidak dianjurkan karena sensor intraoral yang dimasukan ke dalam mulut dapat menjadi transmisi penyebaran virus COVID-19.

Pada tahun 2003 Newman dan Friedman mengembangkan teknik alternatif dimaksudkan untuk pasien yang tidak bisa mentolerir penempatan sensor intraoral ke dalam mulut ${ }^{7}$. Teknik modifikasi ekstraoral ini ditujukan untuk, pasien dengan developmental disabled, trauma dan trimus yang parah, kesulitan anatomi seperti makroglosia, palatum pendek, pasien yang tidak bisa membuka mulut lebar seperti asneurological difficulties, pasien dengan dental phobia yang parah dan untuk anak-anak yang rongga mulutnya terlalu kecil untuk dimasukan sensor intraoral. ${ }^{8}$ Dengan demikian sekelompok besar pasien tidak dapat mentolerir penempatan sensor intraoral di mulut mereka terlebih pada radiografi digital dikarenakan kekakuan dan ketebalan sensor intraoral radiografi digital. Newman dan Friedman telah memperkenalkan sebuah teknik radiografi ekstraoral untuk gigi maksila dan mandibula.

\section{MAKSILA}

Pasien duduk dengan posisi tegak dan membuka mulut semaksimal mungkin agar tabung pesawat sinar-X dapat mengarah ke sensor tanpa terhalang dari sisi mulut yang berlawanan, sehingga superimposisi jaringan kontralateral pada gambar dapat dihindari. Sensor kemudian diletakkan pada permukaan eksternal dari pipi, sejajar dengan bukal dan gigi. Gulungan kapas diletakkan antara sensor dan pipi, sensor parare dengan permukaan bukal dari gigi. Kemudian tabung pesawat sinar- $X$ harus miring sekitar $-55^{\circ}$ dari horizontal. Selain itu, tabung pesawat sinar- $X$ harus tegak lurus dengan sensor untuk memberikan gambar yang akurat (Gambar 1). Penambahan waktu pemaparan mungkin diperlukan ketika radiografi konvensional digunakan, sedangkan radiografi digital tidak memerlukan penambahan waktu pemaparan karena gambar dapat disesuaikan secara digital (enhancement) dalam program perangkat lunak radiografi.

\section{MANDIBULA}

Pasien duduk dengan posisi tegak dan dagu pasien harus dinaikkan, yang memungkinkan sinar$X$ melewati sensor tanpa terhalang, sehingga menghindari superimposisi jaringan kontralateral pada gambar. Lalu sensor harus ditempatkan pada permukaan eksternal pipi, langsung bukal ke gigi. Gulungan kapas ditempatkan di antara sensor dan pipi untuk menyejajarkan sensor dengan permukaan bukal gigi. Kemudian tabung pesawat sinar- $X$ harus miring sekitar $35^{\circ}$ dari horizontal. Selain itu, tabung pesawat sinar- $X$ harus sejajar tegak lurus dengan sensor untuk memberikan gambar yang akurat (Gambar 2). Menambahkan waktu pemaparan mungkin diperlukan.

Pada tahun 2007 Chen et al. mengembangkan alat sensor alignment beam yang bertujuan untuk melakukan radiografi menggunakan teknik ini dan perangkat tersebut berhasil digunakan dalam teknik eksraoral. ${ }^{9}$ Saberi et al. kemudian melakukan penelitian dan hal yang paling penting diperhatikan adalah sudut vertikal dan sudut horizontal, yang berbeda dengan studi Newman dan Friedman. Karena pada teknik Newman dan Friedman memperkenalkan sudut vertikal tanpa mengacu pada anatomi landmark untuk titik masuk sinar pusat dan lokasi pasti dari film atau sensor, hal ini bertentangan dengan kebiasaan dalam prosedur instruksional radiologi oral.

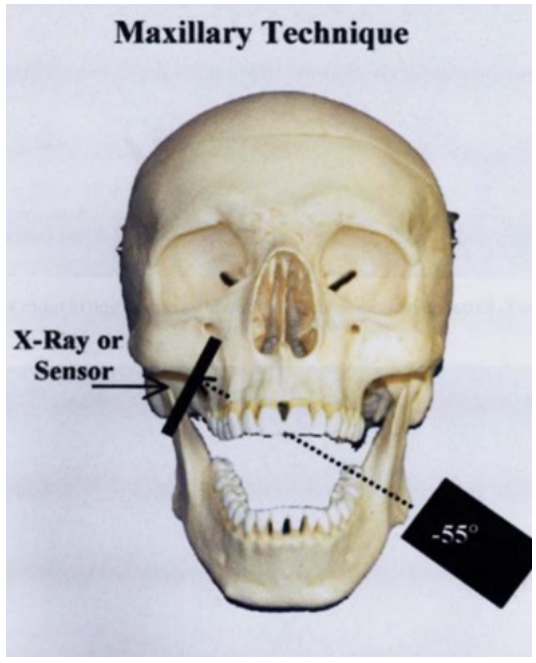

Gambar 1. Teknik radiografi ekstraoral untuk lengkung rahang atas

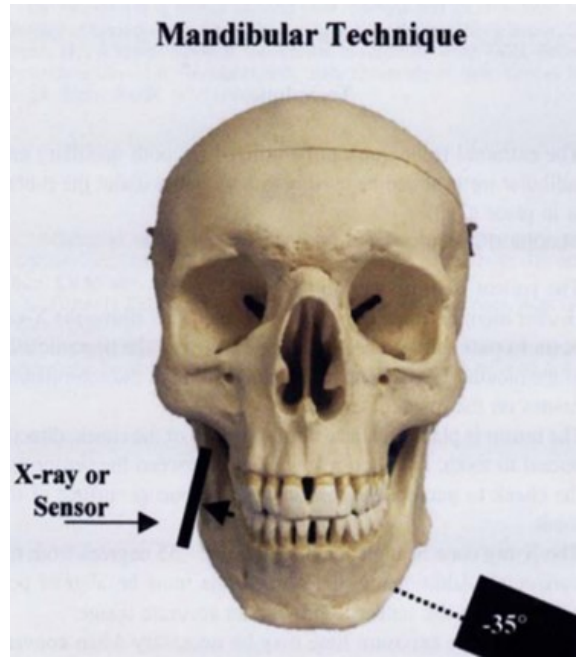

Gambar 2. Teknik radiografi ekstraoral untuk lengkung rahang bawah ${ }^{7}$ 


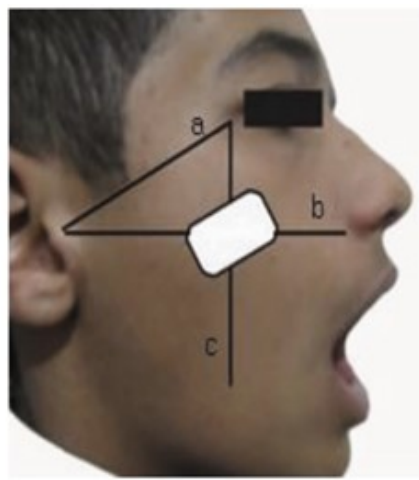

Gambar 3. Lokasi penempatan sensor atau film untuk gigi premolar maksila pada teknik Newman dan Friedman, dan landmark anatomi terlihat pada profil pasien (a) garis canthomeatal; (b) ala-tragus; (c) garis parasagittal ${ }^{8}$
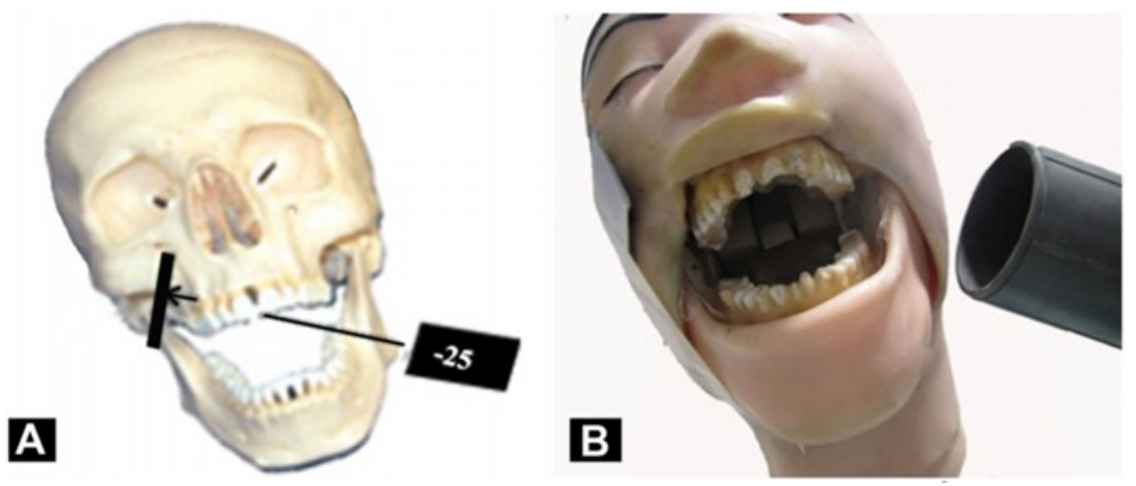

Gambar 4. (A) Angulasi tabung pesawat sinar-X untuk posterior rahang atas: cone diposisikan $-25^{\circ}$ dari horizontal plane. Tempatkan reseptor berlawanan terhadap pipi phantom; b) kepala dimiringkan $10^{\circ}$ menuju sisi yang diperiksa ${ }^{8}$

\section{PREMOLAR MAKSILA}

Posisi pasien dan reseptor: Pasien duduk dengan posisi tegak sementara Frankfort horizontal plane sejajar dengan lantai dan mulut dibuka lebar kemudian kepala dimiringkan $+/-10^{\circ}$ ke samping. Center dari reseptor berada pada persimpangan ala -tragus dan garis parasagittal (yang dimulai dari canthus luar) dan batas atas dari reseptor paralel dengan garis canthomeatal (garis ini bersatu dengan titik pusat eksternal kanal pendengaran ke canthus terluar dari mata) (Gambar 3).

Posisi dari pusat sinar- $X$ : tabung pesawat sinar- $X$ miring $+/--25^{\circ}$ dari garis horizontal sementara pusat sinar diarahkan diantara premolar maksila dan mandibula pada posisi yang berlawanan dari pusat reseptor (Gambar 4). Pesawat intraoral sinar-X digunakan dengan setting 66KVP, $8 \mathrm{MA}, 0.7$ detik.

\section{MOLAR MAKSILA}

Posisi pasien dan reseptor: posisi sama seperti premolar maksila. Pusat dari reseptor berada pada intersection dari ala-tragus dan garis parasagittal dan batas atas dari reseptor parallel dengan garis canthomeatal. Posisi dari pusat sinar-X: tabung pesawat sinar-X dimiringkan $\pm-25^{\circ}$ dari bidang horizontal, sementara pusat sinar diarahkan diantara molar maksila dan mandibula dari posisi yang berlawanan dari pusat reseptor. Contoh hasil radiograf pada daerah posterior rahang atas tampak pada Gambar 5.

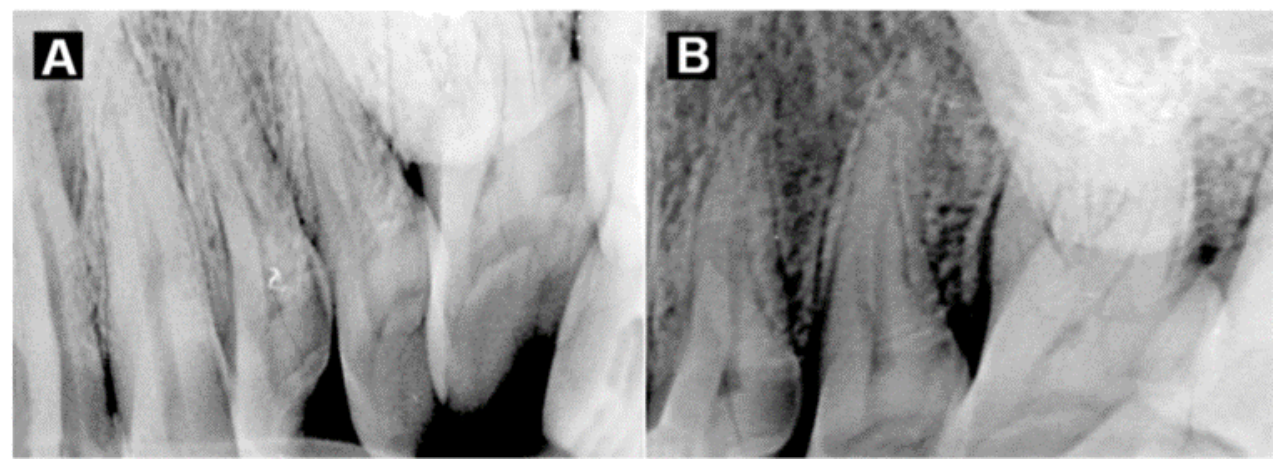

Gambar 5. Gambar radiograf yang dihasilkan dari daerah posterior rahang atas, (A) premolar dan (B) molar $^{8}$ 


\section{PREMOLAR \& MOLAR MANDIBULA}

Posisi pasien dan reseptor: posisi sama dengan maksila. Reseptor ditempatkan pada pipi pasien pada sisi yang diinginkan dan batas bawahnya sejajar dan setidaknya $2 \mathrm{~cm}$ di atas batas inferior mandibula (batas bawah reseptor kira-kira pada CEJ gigi yang akan diradiografi). Posisi pusat sinar- $X$ : tabung pesawat sinar- $\mathrm{X}$ miring sekitar $-20^{\circ}$ dari bidang horizontal sedangkan pusat sinar diarahkan dari $1 \mathrm{~cm}$ di bawah batas bawah dari mandibula $\mathrm{d}$ daerah premolar / molar kontralateral ke pusat reseptor.

\section{DISKUSI}

Pandemi COVID-19 merupakan masalah kesehatan terpenting di dunia saat ini. Penyebaran COVID-19 adalah melalui kontak langsung atau dekat dengan sekresi atau tetesan aerosol yang terinfeksi. Prosedur kedokteran gigi, terutama penggunaan perangkat ultrasonik dan handpiece gigi berkecepatan tinggi menyebabkan pelepasan aerosol, dan pemeriksaan gigi rutin telah ditangguhkan di beberapa negara, termasuk Indonesia, untuk mengurangi penularan virus. Namun, untuk perawatan gigi darurat, seperti pada infeksi odontogenik atau trauma, harus dilengkapi dengan alat pelindung diri yang tepat. Individu dengan COVID-19 mungkin asimptomatik atau presimptomatik (20-86\% dari semua infeksi). Dengan demikian, pasien asimptomatik dengan COVID-19 yang tidak terdiagnosis datang ke klinik gigi. ${ }^{10}$ Pada instalasi radiologi kedokteran gigi yang merupakan bagian dari suatu klinik gigi dapat menjadi sarana utama transmisi COVID-19 melalui sensor intraoral yang dimasukan ke dalam rongga mulut, karena jika sensor intraoral didesinfeksi dengan cairan disinfektan dapat mempengaruhi kualitas radiograf dan merusak informasi diagnostik. Dengan menggunakan teknik modifikasi ekstraoral radiografi Newman dan Friedman dapat mencegah penularan COVID-19.

Newman dan Friedman ${ }^{7}$ menggunakan angulas $-55^{\circ}$ untuk gigi maksila dan $-35^{\circ}$ untuk gigi mandibula. Chen et al $^{9}$ menganjurkan penggunaan angulasi yang lebih rendah daripada yang diberikan oleh Newmann dan Friedman $\left(-20^{\circ}\right.$ sampai $-30^{\circ}$ untuk gigi maksila; $-10^{\circ}$ sampai $-15^{\circ}$ untuk gig mandibula dengan mengacu pada bidang horizontal). Sedangkan pada penelitian Rahul Kumar et al menggunakan angulasi $-25^{\circ}$ untuk gig maksila dan $-15^{\circ}$ untuk gigi rahang bawah. Namun angulasi dapat diubah sesuai dengan perbedaan ras dalam ketinggian wajah. ${ }^{10}$

Keuntungan dari teknik modifikasi ekstraoral radiografi Newman dan Friedman adalah memberikan gambaran dengan detail dan kualitas diagnostik yang memadai pada pasien dengan keterbatasan. Namun, kelemahan dari teknik ini adalah prosedur menjadi teknik yang sensitif, resolusi gambar yang sedikit lebih rendah, dan ketidakmampuan untuk mendapatkan radiografi gigi anterior ${ }^{10}$ serta untuk mendapatkan radiografi ekstraoral yang tepat selama perawatan endodontik sulit karena jarak yang jauh antara sumber x-ray dan reseptor dan oleh karena itu kadang harus dilakukan pemaparan beberapa kali ke pasien. ${ }^{11}$

Dengan kemajuan terbaru dalam radiologi gigi, berbagai teknik seperti radiografi panoramik tersedia untuk pasien namun teknik modifikasi ekstraoral radiografi Newman dan Friedman dapat direkomendasikan di klinik gigi tanpa radiografi panoramik dan pada masa pandemik COVID-19.

\section{KESIMPULAN}

Kesimpulannya, teknik ini tidak dimaksudkan untuk menggantikan radiografi intraoral periapikal konvensional, bagaimanapun dapat digunakan sebagai alternatif radiografi intraoral periapikal ketika sensor intraoral sulit untuk ditempatkan di dalam mulut pasien atau pada masa pandemi COVID-19 seperti sekarang ini. Kam merekomendasikan standarisasi lebih lanjut dari teknik ini untuk kualitas gambar yang lebih baik.

\section{DAFTAR PUSTAKA}

1. Sahu KK, Mishra AK, Lal A. Comprehensive update on current outbreak of novel coronavirus infection (2019-nCoV). Ann Transl Med 2020. doi: 10.21037/atm.2020.02.92.

"Coronavirus Update Worldwide". Worldometer. Retrieved 27 May 2020

3. World Health Organization. 2020b. Rational use of personal protective equipment (PPE) for coronavirus disease (COVID19). World Health Organisation [accessed 2020 April 4] https://apps.who.int/iris/bitstream/ handle/10665/331498/ WHO-2019-nCoV-IPCPPE use-2020.2-eng.pdf

4. White SC, Pharoah MJ. Oral Radiology Principles and Interpretation. 7th ed. Elsevier: Mosby. 2014. p86-89.

5. Whaites E, Drage N. Essentials of Dental Radiography and Radiology. 5th ed. Elsevier: Churchill Livingstone. 2013. p85 113.

6. Brezniak, N., Goren, S., \& Zoizner, R. (2004). The Use of an Individual Jig in Measuring Tooth Length Changes, 74(6), 780 -785 .

7. Newman ME, Friedman S. Extraoral radiographic technique: an alternative approach. J Endod 2003; 29 : 419-21. 4.

8. Eshagali Saberi, Ladan Hafezi, Narges Farhadmolashahi, Manoochehr Mokhtari. Modified Newman and Friedman Extraoral Radiographic Technique IEJ Iranian Endodontic Journal 2012;7(2):74-78.

9. Chen $\mathrm{CH}$, Lin SH, Chiu HL, Lin YJ, Chen YK, Lin LM. An aiming device for an extraoral radiographic technique. J Endod 2007; 33 : 758-60.

10. Li R, Pei S, Chen B, et al. Substantial undocumented infection facilitates the rapid dissemination of novel coronavirus (SARS -CoV2). Science 2020; 368: 489-493

11. Rahul Kumar, Neha Khambete, Ekta Priya: Extraoral periapical radiography: an alternative approach to intraoral periapical radiography. Imaging Science in Dentistry 2011; 41 : 161-5 http://dx.doi.org/10.5624/isd.2011.41.4.161. 